11 Preble OT, Black RJ, Friedman RM, Klippel JH, Vilcek J. Systemic lupus erythematosus: presence in human serum of an unusual acidlabile leukocyte interferon. Science $1982 ; 216: 429-31$.

12 Ytterberg SR, Schnitzer TJ. Serum interferon levels in patients with systemic lupus erythematosus. Arthritis Rheum 1982;25:401-6.

${ }^{13}$ Hooks JJ, Jordan GW, Cupps T, Moutsopoulos HM, Fauci AS, Notkins AL. Multiple interferons in the circulation of patients with systemic lupus erythematosus and vasculitis. Arthritis Rheum $1982 ; 25: 396-400$.

${ }_{14}$ Neighbour PA, Grayzel AE. Interferon production in vitro by leukocytes from patients with systemic lupus erythematosus and rheumatoid arthritis. Clin Exp Immunol 1981;45:576-81.

${ }^{15}$ Luby JP, Sanders CV, Sulkin SE. Interferon assays and quantitative virus determination in a fatal infection in man with Western equine encephalomyelitis virus. Am 7 Trop Med Hyg 1971 ;20:765-9.

16 Lebon P, Ponsot G, Aicardi J, Goutières F, Arthuis M. Early intrathecal synthesis of interferon in herpes encephalitis. Biomedicine 1979;31: 267-71

${ }^{17}$ Legaspi RC, Gatmaitan B, Bailey EJ, Lerner AM. Interferon in biopsy and autopsy specimens of brain: its presence in herpes simplex virus encephalitis. Arch Neurol 1980;37:76-9.

18 Vézinet F, Lebon P, Amoudry C, Gibert C. Sythèse d'interféron au cours des encéphalites herpétiques de l'adulte. Presse Médicale 1981;10: 1135-8.

19 Trinchieri G, Santoli D, Knowles BB. Tumour cell lines induce interferon in human lymphocytes. Nature 1977;270:611-3.

${ }^{20}$ Heremans H, Billiau A, Colombatti A, Hilgers J, De Somer P. Interferon treatment of NZB mice: accelerated progression of autoimmune disease. Infect Immun 1978;21:925.

${ }^{21}$ Sergiescu D, Cerutti I, Efthymiou E, Kahan A, Chany C: Adverse effects of interferon treatment on the life span of NZB mice. Biomedicine $1979 ; 31: 48-51$.

${ }^{22}$ Adam C, Thoua Y, Ronco P, Verroust P, Tovey M, Morel-Maroger L. The effect of exogenous interferon: acceleration of autoimmune and renal diseases in NZB/W F1 mice. Clin Exp Immunol 1980;40:373-82.

(Accepted 22 fuly 1983)

\title{
Ulceration of the hand secondary to a radial arteriovenous fistula: a model for varicose ulceration
}

\author{
M L WOOD，G D REILLY，G T SMITH
}

\begin{abstract}
A patient in whom a radial arteriovenous fistula was constructed in preparation for haemodialysis subsequently developed ulceration on the dorsum of the hand. The lesion failed to heal despite antibiotic treatment, and so the fistula was closed. The lesion healed within three weeks. Subsequent construction of a fistula at the right wrist was followed 12 months later by the development of similar ulceration of the right hand.

This complication of arteriovenous fistulas is similar to varicose ulceration of the leg and provides a unique opportunity to study the effects of sustained venous hypertension on the skin.
\end{abstract}

\section{Introduction}

Ulceration of the hand may develop as a complication of arteriovenous fistulas. We report on a patient with this complication.

\section{Case report}

A side to side arteriovenous fistula was constructed at the left wrist between the dorsal radial artery and vein in preparation for haemodialysis in a 48 year old woman with chronic renal failure secondary to diabetic nephropathy. Her renal failure was managed conservatively, and the blood urea concentration remained raised at around $40 \mathrm{mmol} / \mathrm{l}$ $(240 \mathrm{mg} / 100 \mathrm{ml})$. Eighteen months later she presented to the dermatology outpatients department with swelling of the left hand and an erythematous and indurated area on the dorsum of the hand between

\footnotetext{
Rupert Hallam Department of Dermatology, Royal Hallamshire Hospital, Sheffield S10 2JF

$M$ L WOOD, MB, MRCP, senior registrar

G D REILLY, MA, MRCP, registrar

Department of Pathology, Royal Hallamshire Hospital

G T SMITH, MB, MRCPATH, lecturer

Correspondence to: Dr M L Wood.
}

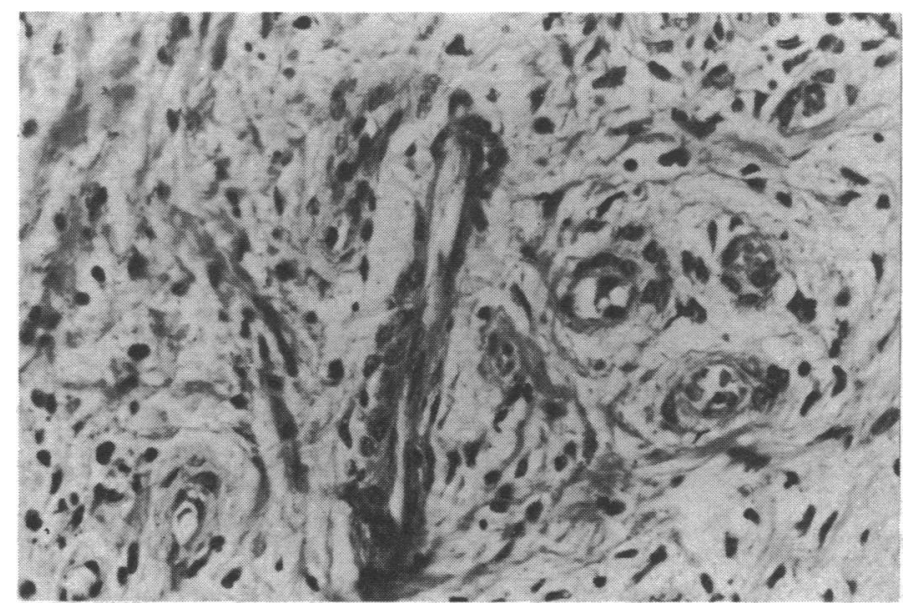

Biopsy specimen showing thick walled capillaries with plump endothelial cells in upper dermis. Haematoxylin and eosin $\times 210$.

the thumb and the index finger, which had been present for about six months. She was not feverish and was otherwise well.

A skin swab grew Staphylococcus pyogenes, and she was given a course of oral erythromycin $250 \mathrm{mg}$ four times a day. The lesion failed to heal, and a small ulcer developed over the proximal phalanx of the index finger. A biopsy specimen of the edge of the ulcer (figure) showed thick walled capillaries with plump endothelial cells in a mildly oedematous dermis. Larger vessels showed intimal proliferation. The thickened eosinophilic capillary walls and pericapillary tissue showed focal positive staining for fibrin by the peroxidase antiperoxidase technique. There was a light mixed inflammatory cell infiltrate including eosinophils in the dermis.

Because of the persisting ulceration the fistula at the left wrist was closed; within three weeks the lesion had healed. A further fistula was fashioned at the right wrist, and 12 months later she began to develop a similar erythematous, indurated area on the dorsum of the right hand.

\section{Discussion}

Ulceration of the hand as a complication of arteriovenous fistulas has been described previously. ${ }^{1}$ It is thought to result from retrograde venous arterialisation, the high pressure in the 
veins draining the hand causing swelling, induration of the skin, and eventual ulceration. Construction of a fistula linking the end of the vein to the side of the artery, with ligation of the venous branch draining the dorsum of the hand, may help avoid this complication.

Sustained venous hypertension on the skin capillaries of the canine hind limb causes an increase in the number and permeability of dermal capillaries with increased leakage of fibrinogen into the interstitium. ${ }^{2} \mathrm{~A}$ recent study on ulcer bearing skin of the leg in man showed layers of fibrin surrounding the dermal capillaries, and it has been postulated that extravascular fibrin stimulates tissue fibrosis and blocks the diffusion of oxygen to the overlying epidermis, resulting in ulceration. ${ }^{3}$ Histological examination of our patient's skin showed this capillary proliferation and the pericapillary fibrin that are the hallmark of venous hypertension.
We believe that this complication of arteriovenous fistulas is under reported and provides a unique opportunity to observe the effects of sustained venous hypertension on the skin in man similar to that seen in varicose ulceration of leg.

\section{References}

${ }^{1}$ Haimov M, Baez A, Neff M, Slifkin R. Complications of arteriovenous fistulas for haemodialysis. Arch Surg 1975;110:708-12.

2 Burnand KG, Clemenson G, Whimster I, Gount J, Browse NL. The effect of sustained venous hypertension on the skin capillaries of the canine hind limb. Br $\mathcal{F}$ Surg $1982 ; 69: 41-4$.

${ }^{3}$ Burnand KG, Whimster I, Naidoo A, Browse NL. Pericapillary fibrin in the ulcer-bearing skin of the leg: the cause of lipodermatosclerosis and venous ulceration. $\mathrm{Br} \mathrm{Med} \mathcal{F}$ 1982;285:1071-2.

(Accepted 6 fuly 1983)

\title{
Severe diabetic microangiopathy with normal glucose tolerance and pituitary infarction
}

\author{
R W BILOUS, R N POSTON, H KEEN, G C VIBERTI
}

\begin{abstract}
Blood glucose concentrations in a woman with severe retinopathy, nephropathy, and neuropathy were found to be within the normal range. A high random blood glucose concentration was recorded only once, six months before her initial presentation. At necropsy the anterior lobe of the pituitary gland showed old, extensive infarction.
\end{abstract}

Occult pituitary hypofunction may explain severe diabetic microangiopathy in patients with normal glucose tolerance.

\section{Introduction}

In 1936 Houssay described the ameliorating effect of hypophysectomy on hyperglycaemia and ketosis in dogs that had undergone pancreatectomy. ${ }^{1}$ Many studies on the influence of pituitary function on diabetes and its complications have since been reported. ${ }^{2}$ We report on a patient with severe retinopathy, nephropathy, and neuropathy in the absence of diabetes mellitus at the time of presentation. Postmortem examination showed infarction of the pituitary gland.

\section{Case report}

A 44 year old woman presented to this hospital in July 1978 complaining of blurred vision. In December 1977 she had been admitted

Unit for Metabolic Medicine, Guy's Hospital Medical School, London SE1 9RT

R W BILOUS, BSC, MRCP, research registrar

H KEEN, MD, FRCP, professor

G C VIBERTI, $M D$, senior research fellow

Department of Histopathology, Guy's Hospital Medical School R N POSTON, MRCPATH, lecturer

Correspondence and requests for reprints to: $\mathrm{Dr} R \mathrm{~W}$ Bilous, St Helier Hospital, Carshalton, Surrey. to another hospital with a superficial loin carbuncle, when glycosuria and a random blood glucose concentration of $17.6 \mathrm{mmol} / 1(317 \mathrm{mg} / 100$ $\mathrm{ml}$ ) had been recorded. She had also had heavy proteinuria, with a creatinine clearance of $52 \mathrm{ml} / \mathrm{min} / 1.73 \mathrm{~m}^{2}$. She had been given a single injection of 20 units of insulin before drainage of the abscess but thereafter had been treated with only dietary restriction. Blood glucose concentrations had returned promptly to the normal range. No formal glucose tolerance test had been performed.

On initial examination at this hospital she was obese $(90 \mathrm{~kg})$ with facial hirsutism and hypertension $(196 / 126 \mathrm{~mm} \mathrm{Hg})$. She had severe bilateral proliferative retinopathy with acuity reduced to $3 / 60$ on the right and $3 / 2$ on the left. Ankle reflexes and pin prick and vibration sensation were absent in both legs.

After fluoroscein angiography she underwent right laser photocoagulation, but a vitreous haemorrhage blinded her in November 1978. Investigations showed proteinuria of $2.5 \mathrm{~g} / 24 \mathrm{~h}$ and a glomerular filtration rate (edetic acid labelled with ${ }^{51} \mathrm{Cr}$ ) of $51 \mathrm{ml} / \mathrm{min} / 1.73 \mathrm{~m}^{2}$. A $75 \mathrm{~g}$ oral glucose tolerance test showed only impaired glucose tolerance (table). Her hypertension responded to beta blockers, and an intravenous urogram was normal. Left percutaneous renal biopsy in January 1979 confirmed diabetic glomerulosclerosis. Blood glucose concentrations on multiple occasions over this period never exceeded $6 \cdot 1 \mathrm{mmol} / 1(110 \mathrm{mg} / 100 \mathrm{ml})$. By June 1980 the glomerular filtration rate (edetic acid labelled with ${ }^{51} \mathrm{Cr}$ ) had declined to $13 \mathrm{ml} / \mathrm{min} / 1 \cdot 73$ $\mathrm{m}^{2}$; a second oral glucose tolerance test was performed, during which both plasma growth hormone and insulin concentrations were measured (table). Results of thyroid function tests, morning and evening plasma cortisol concentrations, and urinary free cortisol excretion were normal. She declined to undergo insulin stress test. By

Plasma glucose and growth hormone concentrations after $75 \mathrm{~g}$ oral glucose tolerance tests at presentation and two years later

\begin{tabular}{lccc}
\hline & & \multicolumn{2}{c}{ 16 June 1980 } \\
\cline { 3 - 4 } Time after glucose & $\begin{array}{c}\text { 23 August } 1978 \\
\text { Plasma glucose } \\
\text { load }\end{array}$ & $\begin{array}{c}\text { Plasma glucose } \\
(\mathrm{mmol} / \mathrm{l})\end{array}$ & $\begin{array}{c}\text { Growth hormone } \\
(\mathrm{mU} / \mathrm{l})\end{array}$ \\
\hline Fasting & $5 \cdot 9$ & $4 \cdot 1$ & 1 \\
$30 \mathrm{~min}$ & $8 \cdot 0$ & $5 \cdot 7$ & 1 \\
$60 \mathrm{~min}$ & $8 \cdot 0$ & $6 \cdot 9$ & 1 \\
$90 \mathrm{~min}$ & $8 \cdot 5$ & $6 \cdot 8$ & 1 \\
$120 \mathrm{~min}$ & $7 \cdot 3$ & $7 \cdot 2$ & 1 \\
$150 \mathrm{~min}$ & & $5 \cdot 2$ & 1 \\
$180 \mathrm{~min}$ & & $4 \cdot 3$ & 1 \\
$240 \mathrm{~min}$ & & $3 \cdot 9$ & 0 \\
$300 \mathrm{~min}$ & & &
\end{tabular}

Conversion: SI to traditional units-Glucose: $1 \mathrm{mmol} / 1 \approx 18 \mathrm{mg} / 100 \mathrm{ml}$. 